specific introduction, rather than the reader being reliant on a brief preface. Secondly, the volume's title, Intersections: Women on Law, Medicine and Tech$n o \log y$, does not direct the reader to the stated aim in the preface, that of dissecting medical power. This title alerts the reader to the fact that the authors are women. However, while many of the essays in the collection do provide a feminist slant to the discussion of particular health care issues (for example, Anlue's discussion of Reproductive autonomy and reproductive technology: gender, deviance and infertility, and Darvell's essay, Gender and equity: emerging issues in Australian drug trial regulatory policies,) and many of the essays centre upon issues particularly pertinent to women, this is not a collection of essays designed to provide a feminist critique of medical power. For a more comprehensive examination of feminist issues in the health care context the reader would need to look elsewhere, to collections such as that edited by Sheldon and Thomson, Feminist Perspectives of Health Care, which was published by Cavendish in 1997).

Inevitably in a collection such as this, there are issues which the reviewer would have hoped would have been addressed. It is of course unfair to say to the authors that one would have structured a volume in another way, etc and there is much of interest and of value in this particular collection, not least in its comparative discussions. I was, however, at least a little disappointed that the impact on medical power of professional selfregulation, statutory regulation and other measures such as clinical audit were not afforded greater consideration. These are surely important issues for a volume dissecting medical power and the role of technology today, a volume moreover which states that it aims to provide a "coherent framework for law and policy making". The nature of the boundaries between medical power itself and that wielded by the scientist in the biotechnological context (as, for example, discussed by Gannon in her essay, The science of biotechnology: present, past and future quagmires,) perhaps merited further consideration. Is the role of the scientist and of the doctor identical? Does this impact upon the appropriate regulatory mechanisms to be adopted? One final reflection. Overall this collection draws upon some interesting cross-jurisdictional comparisons. It raises some important themes and leaves the reader wanting to explore the issue further.

JV MCHALE

Senior Lecturer in Law, Faculty of Law, University of Manchester

\section{Sharing the Journey: Spiritual Assessment and Pastoral Response to Persons with Incurable Illnesses}

Cornelius J van der Poel, Minnesota, Liturgical Press, 1998, 94 pages, US\$9.95.

The author of this book has taught ethics and pastoral theology as well as having served as a chaplain within a health care setting prior to retirement. Sharing the fourney seeks to differentiate between religious denomination and a broader spiritual perspective and focuses on people who have AIDS, cancer or multiple sclerosis, recognising that the assessment and evaluation of a patient's needs in respect of spiritual care is far from easy. The author offers an instrument for spiritual assessment which will allow the carer to evaluate the spiritual state of the person to whom care is being given.

The first part of the book outlines an understanding of the nature of spirituality and the differentiation of spiritual from psychological states, focusing in particular on key words of faith, hope and love.

The key aspects of the assessment document are five general questions dealing with:

1. The place of God in the patient's life;

2. The patient's attitude towards him or herself;

3. The patient's relationship with family and friends;

4. The patient's understanding of and interest in prayer;

5. The patient's attitude toward his or her religious denomination or church.

Each question then has four statements and each assessment has a score of 1 to 5, ranging from strong disagreement to strong agreement.

The next chapter discusses the applicability of this instrument in respect of three situations/illnesses which impa鸟 on patients and families. This is then followed by a chapter focusing $\overline{\bar{y}}$ pastoral responsibility and looking $\vec{f}$ ways in which pastors or chaplains might plan suitable intervention. Rea娄 ers may recoil from the description "a pastoral treatment plan" (page 74 ) and one of the problems presented tof this book is the difficulty of using such instruments in the general care and management of patients. There is some recognition of this in that the authes envisages chaplains might choose make the assessment retrospectivela, following interaction with the patien and this would seem to be a less intries sive way. This would then give thio chaplain a way of reflecting on areas $\mathscr{\leftrightarrow}$ development or regression in the ore going relationship with the patient.

From an ethical perspective it feets important that the development an use of such instruments does not override the autonomy of the indio vidual and his/her ability to say "No to being so assessed. Issues might also arise regarding confidentiality: fears about information becoming access ble to other team members and othe professionals involved in the care. would also seem important that suc $\$$ an instrument, if it were to be use should not be included on the basis of implied consent but with the specific consent of the patient being sough each time.

REVEREND PREBENDAR
PETER SPEC
Trust Chaplaincy Team Lead
$\begin{aligned} & \text { Books: information and } \\ & \text { orders }\end{aligned}$

If you wish to order or require furth information regarding the titles reviewed here, please write or telephon the BMJ Bookshop, PO Box 295 London WC1H 9JR. Tel: 017138$\}$ 6244; fax: 0171383 6455; Internet www.bmjbookshop.com; emaida orders@bmjbookshop.com. Europear customers should add 15 per cent fom postage and packing, other overseas customers should add $30 \%$. Payment can be made by cheque in sterling drawn on a UK bank or by credit car\& (Mastercard,Visa, or American Ex press, stating card number, expiry date and full name. (The price and availa bality are occasionally subject to revision by the publishers.) 